\title{
Deacetylation of Androgen Receptor by SIRT2 and its Dysregulation Promotes Pathogenesis and Progression of Prostate Cancer
}

\author{
Androjen Reseptörünün SIRT2 ile Diasetilasyonu ve Bundaki Eksiklik Prostat Kanseri Patojenite \\ ve Ilerlemesini Uyarır
}

\author{
Özkan Özden \\ Kafkas Üniversitesi Mühendislik Mimarlkk Fakültesi, Biyomühendislik Bölümü, Kars, Türkiye
}

\begin{abstract}
Aim: The purpose of the study was to investigate whether the androgen receptor (AR) whose activity is closely associated with prostate cancer is post-translationally regulated by a NAD+ dependent and aging associated protein, sirtuin2 (SIRT2).

Material and Method: Immunoprecipitation-Western blotting was conducted to examine the association of the AR and SIRT2 in cultured $293 T$ and $L N C a P$ cells. In addition, we performed in vitro deacetylation assays using purified SIRT2 and AR proteins.

Results: SIRT2 gene removal mouse prostate had hyper-acetylated the $A R$. In vitro and in vivo interaction assays revealed that SIRT2 physically interacted with the AR in prostate cancer cell line $L N C a P$. Finally, SIRT2 deacetylated the $A R$ in vitro conditions.

Conclusion: SIRT2 interacted with the $A R$ and deacetylated it. Identifying partners of the $A R$ and molecular mechanisms of its regulation is curial for understanding the pathogenesis of prostate cancer. Using small molecules to activate SIRT2 might be an important clinical approach to prevent, treat or delay the prostate cancer progression.
\end{abstract}

Key words: prostate; cancer; post-translational regulation; sirtuin; deacetylation

\section{ÖZET}

Amaç: Bu çalıșmanın amacı, aktivitesi prostat kanseriyle yakın ilișkili olan androjen reseptörünün (AR), $N A D^{+}$'ye bağımlı ve yașlanmayla alakalı bir protein olan sirtuin2 (SIRT2) tarafindan posttranslasyonel olarak düzenlenmesini araștırmaktır.

Materyal ve Metot: Immunolojik çökeltme-Western blot teknikleriyle $A R$ ve SIRT2 arasındaki etkileșim $293 T$ ve $L N C a P$ hücre kültürlerinde incelenmiștir. Ilaveten, saflaștırılmıș SIRT2 ve AR proteinleriyle in vitro diasetilasyon çalıșmaları yapılmıștır.

Özkan Özden, Kafkas Üniversitesi Mühendislik Mimarllk Fakültesi Biyomühendislik Bölümü, Kars - Türkiye, Tel.05365645229Email.ozzkan1@gmail.com

Geliş Tarihi: 03.06.2016 • Kabul Tarihi: 30.11.2016
Bulgular: SIRT2 geni uzaklaștırılmıș farenin prostatındaki AR așırı derecede asetile edildi. In vitro ve in vivo etkileșim deneyleri SIRT2'nin AR'la fiziksel etkileșim gösterdiğini ortaya çıkarttı. Son olarak, SIRT2, AR'ı in vitro koșullarda diasetile etti.

Sonuç: SIRT2, AR ile etkileșim kurup onu diasetile etti. AR'a bağlanan diğer proteinler ve onun düzenlenmesinin moleküler mekanizmasını tanımlamak, prostat kanserinin patojenitesini anlamak açısından büyük bir öneme sahiptir. SIRT2'yi küçük moleküller aracllyla aktive etmek prostat kanserinin engelleme, tedavi etme veya gelișimini yavașlatmak açısından klinik öneme sahip olabilir.

Anahtar kelimeler: prostat; kanser; post-translasyonel düzenleme; sirtuin; diasetilasyon

\section{Introduction}

Prostate cancer is the most common non-skin cancer, and in 2016 there will be approximately 180,890 new cases of prostate cancer and an estimated 26,120 people will die of this disease in the USA ${ }^{1}$. Androgen receptor $(A R)$ and its downstream signaling play a crucial role in the normal development and function of the prostate ${ }^{2,3}$. AR is a DNA-binding transcription factor governing the development and maintenance of the male sexual phenotype. Upon binding of androgenic hormones, such as testosterone or dihydrotestosterone (DHT) in the cytoplasm, the AR translocates into the nucleus and regulates the expression of genes related to differentiation, proliferation, and apoptosis ${ }^{4}$. Abnormal function of the AR has been proposed to be one of the main reasons for the progression of human prostate cancer ${ }^{5,6}$. Decrease in AR activity through androgen suppression is one of the hormonal treatment strategies for prostate cancer ${ }^{3,7}$. Post-translational modifications of the AR by phosphorylation, sumoylation, 
and acetylation direct its subcellular localization, association with co-activators or co-repressors, and DNA binding ability ${ }^{8-10}$. It has been shown that AR is acetylated by histone acetyltransferases (HATs), including p300, P/CAF, and TIP60; and consequently activated $^{8}$. Acetylation of AR by these HATs increases its access to androgen-responsive elements activity which might be the physiological consequence of hormoneactivated AR signaling with testosterone or $\mathrm{DHT}^{11}$.

Sirtuin (SIRT) deacetylases have seven members in mammals and the silent information regulator 2 (Sir2) protein in Saccharomyces cerevisiae is the founding member of this protein family. Seven SIRTs are found in different compartments within the cells. SIRT3, 4 and 5 are located in the mitochondria, SIRT 1, 6 and 7 are mainly located in the nuclei, and SIRT2 is primarily located in the cytoplasm but it can translocate into the nucleus during cell cycle ${ }^{12}$. SIRTs have been reported to be involved in aging, longevity, stress response, regulation of metabolism, gene silencing, and DNA repair. SIRT2 is generally considered a tumor suppressor because SIRT2 gene removed mice develop a gender specific tumorigenesis ${ }^{13}$. While male mice primarily develop liver tumors, female mice develop mammary tumors. In addition, these SIRT2 KO mice also developed tumors in the prostate gland ${ }^{13}$. SIRT2 has multiple biological roles such as cell cycle progression, genomic stability, microtubule dynamics, cellular metabolism, and ligand-induced hormone signaling ${ }^{14,15}$.

Although acetylation of AR, and its subsequent activation has been well studied, there is not much known about which deacetylases remove the acetyl groups and its physiological and pathological importance. SIRT1 binds and deacetylates the AR at a conserved lysine aminoacid and represses its transcriptional activity ${ }^{11}$. These investigators suggested that deacetylation of AR may decrease its activity and might help prevent prostate cancer occurrence or progression ${ }^{11,16}$. In our study, we investigated if AR could serve as a direct substrate for the SIRT2 $\mathrm{NAD}^{+}$-dependent deacetylase which may ultimately lead to improvement of clinical approaches for the prevention and treatment of prostate cancer.

\section{Material and Method}

\section{Cell Culture and Transfection}

293T and androgen-sensitive LNCaP human prostate adenocarcinoma cells were maintained in a $37^{\circ} \mathrm{C}$ incubator with $5 \% \mathrm{CO}_{2}$ and $21 \%$ oxygen in Dulbecco's Modified Eagle's medium (DMEM) containing 10\% fetal bovine serum (FBS) as described previously ${ }^{13}$. Transfection efficiency of 293T cells was approximately $70 \%$ as determined using a GFP vector. SIRT2 wild type (WT) and knockout (KO) prostate tissue extracts from $\mathrm{WT}$ and $\mathrm{KO}$ mice were obtained from ${ }^{13}$.

\section{Immunoprecipitation (IP) of HA-tagged SIRT2 and FLAG-tagged AR}

Immunoprecipitation was performed as previously reported $^{15}$. Briefly, HA-tagged SIRT2 and Flag-tagged AR overexpressing 293T cells and LNCAP prostate cancer cell lines were lysed with IP buffer, including protease and phosphatase inhibitors. Total cell extracts were incubated with anti-FLAG (Sigma, St. Louis, MO), anti-HA primary antibodies (Santa Cruz), antiSIRT2 or anti-AR antibodies for $16 \mathrm{~h}$ at $4^{\circ} \mathrm{C}$, followed by the incubation with magnetic beads (Dynabeads; Life Technologies Carlsbad, CA) for $2 \mathrm{~h}$. After washing three times with IP buffer, bound proteins were extracted by boiling the samples in the loading buffer for $7 \mathrm{~min}$, and isolated proteins were resolved via $10 \%$ SDS PAGE.

\section{Western Blotting}

Western blotting on nitrocellulose membrane was performed using Turbo transfer system (BioRad). PVDF membranes were incubated with anti-AR (Santa Cruz), anti-SIRT2 (Sigma), acetyl-lysine (Immunochem), anti-HA (Cell Signaling), and anti-FLAG (Sigma) primary antibodies for $16 \mathrm{~h}$ at $4^{\circ} \mathrm{C}$.

\section{In vitro Deacetylation Assay}

In vitro deacetylation assays was performed as published previously by our lab ${ }^{17}$. Briefly, 293T cells were transiently transfected with FLAG tagged-AR and one of the HATs (p300, P/CAF, and TIP60) with PEI. 24 $h$ after transfection, cells were exposed to trichostatin A (TSA) and nicotinamide (NAM) for $10 \mathrm{~h}$ to hyperacetylate proteins. Next, cells were harvested and lysed with IP buffer, and proteins were isolated. For in vitro deacetylation assay, after isolation of Flag-tagged AR protein, an in vitro deacetylation reaction in a $1.5 \mathrm{~mL}$ Eppendorph tube was set up. Briefly, commercially available recombinant SIRT2 enzyme, hyperacetylated purified AR protein as a substrate, and $\mathrm{NAD}^{+}$co-factor to activate the enzyme were mixed within a tube at $37^{\circ} \mathrm{C}$ for $3 \mathrm{~h}$. 


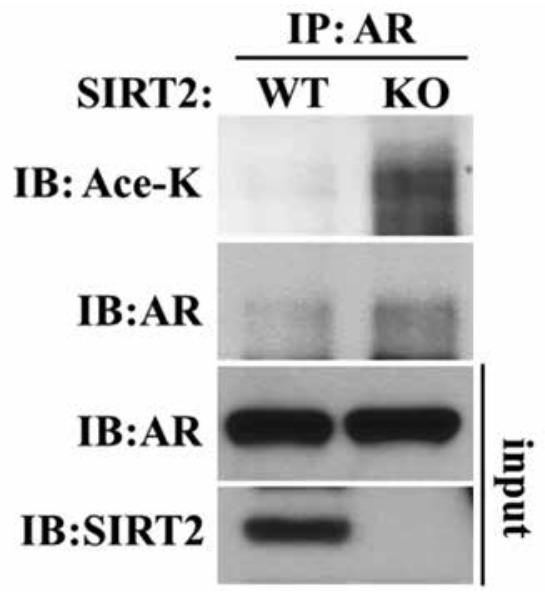

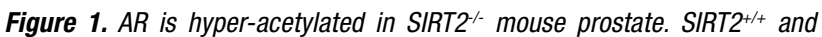
SIRT2- prostate extracts (1 $\mathrm{mg}$ of protein from each) were immunoprecipitated with the anti-AR antibody, separated, and subsequently immunoblotted with an anti-panacetyllysine, and anti-AR as a loading control, and anti-SIRT2 antibody.

\section{Results}

AR is Hyperacetylated in SIRT2 KO (SIRT2 $\left.{ }^{--}\right)$Mouse Prostate

Prostate tissue extracts from Sirt $2^{+/+}$and Sirt $2^{-/}$mice were IPed with anti-FLAG antibody, separated, and subsequently immunoblotted with anti-pan acetyllysine showing that AR exhibited increased protein acetylation in mice lacking SIRT2 enzyme (Fig. 1).

\section{SIRT2 Associates with the AR}

To determine if there is a physical interaction between the AR and SIRT2, an overexpression system was used. 293T cells were transfected with FLAG-AR and HA-SIRT2 followed by immunoprecipitation (IP) with an anti-HA antibody to immunoprecipitate the SIRT2 (Fig. 2a) or anti-FLAG antibody to immunoprecipitate AR (Fig. 2b). Samples were subsequently immunoblotted with either an anti-FLAG antibody to detect the expression of the AR (Fig. 2a) or anti-HA to determine the expression of SIRT2 (Fig. 2b). These results displayed an interaction between SIRT2 and the AR using an exogenous system. (a)



IB: Flag

IB: HA
(AR)

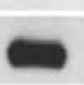

(b)



(c)

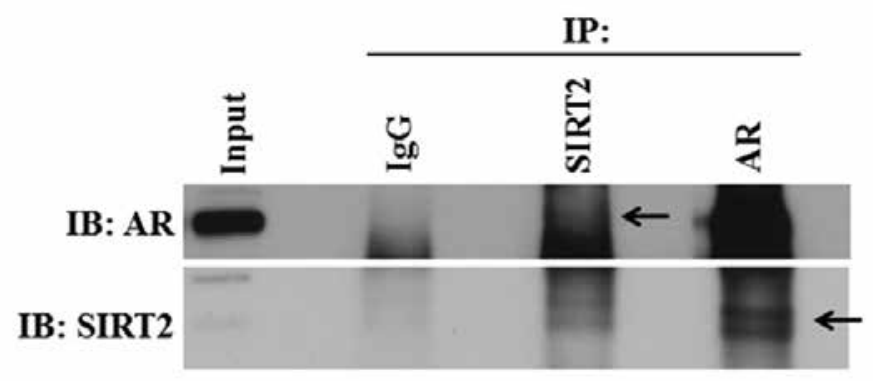

Figure 2. a-c. SIRT2 physically interacts with AR. Protein-protein interaction between SIRT2 and the AR proteins was investigated by an overexpression system using IP and western blotting techniques. HA-tagged SIRT2 and FLAG-tagged AR overepressing 293T cell line extracts were immunoprecipitated with anti-HA (a) or anti-FLAG (b) antibodies, and subsequently immunoblotted with anti-Flag antibody (a) or anti-HA (b). LNCaP cells were harvested and endogenous SIRT2 or AR were immunoprecipitated, separated, and immunoblotted with an anti-AR or anti-SIRT2 antibody. IgG was used as a negative control and AR immunoprecipitation was used as a positive control (c). 
This interaction was also confirmed between endogenous AR and endogenous SIRT2 by IP experiments using anti-AR or anti-SIRT2 antibodies in LNCaP cells (Fig. 2c).

\section{$A R$ is Deacetylated by SIRT2 in vitro}

To determine if the AR is a direct SIRT2 deacetylation target, 293T cells were transiently transfected with $5 \mu \mathrm{g}$ FLAG-AR along with $5 \mu \mathrm{g}$ one of the HATs (p300, P/CAF, and TIP60), and extracts were immunoprecipitated with FLAG antibody to isolate the AR. Isolated $A R$ protein was divided into 6 reactions and each was mixed with recombinant SIRT2, without or with NAD+, followed by immunoblotting with antipanacetyllysine, anti-AR, and anti-SIRT2 antibodies. In vitro deacetylation assay revealed that SIRT2 deacetylated the AR (Fig. 3).

In summary, in this study, we showed that removal of SIRT2 gene in mice resulted in hyperacetylation of the AR in the prostate gland. SIRT2 interacted with the AR in prostate cancer cell line and deacetylated it. These results suggested that SIRT2 regulated acetylation of the AR in the prostate gland.

\section{Discussion}

Prostate cancer is a disease of aging and it more frequently occurs in older men than younger men ${ }^{6}$. SIRTs are closely associated with aging and longevity. Therefore, it is important to identify the contributory connection between mechanisms of aging and prostate cancer. It has been reported that the expression of SIRTs decreases as individuals age and elevated in cancer cells ${ }^{18}$. SIRTs could be one of the connections between aging and age related diseases, such as in prostate cancer. Inhibition of the activity or the expression of the AR through hormonal therapy or modulation of AR signal transduction pathways using small molecules, may prevent or delay prostate cancer progression $^{7,19}$. Therefore, it is important to identify the molecular mechanisms suppressing and activating the AR activity, and SIRT2 can be one of the candidates for this.

SIRT1 interacted with and deacetylated AR in cultured prostate cancer cells; and ultimately repressed AR activity ${ }^{11}$. When these investigators mutated lysine at K630 in the AR, these cells became resistant to SIRT1-mediated AR activity repression indicating the importance of this K630 for acetylation by SIRT $1^{11}$. Likewise, in our study, another SIRT enzyme, SIRT2 interacted with the AR. Acetylation site of AR might be the same for both SIRT1 and SIRT2. Although SIRT1 and SIRT2 have similar aminoacid homology and activity, they display different substrate specificities, subcellular localization, and functions. Deacetylation of AR by both SIRT1 and SIRT2 underscores the importance of acetylation/ deacetylation events, perhaps in different physiological and pathological conditions of the prostate.



Figure 3. SIRT2 deacetylated the AR in vitro. Purified acetylated Flag-AR was mixed with purified SIRT2, without or with NAD+, and samples were immunoblotted with anti-pan acetyl-lysine. As loading controls, anti-AR and anti-SIRT2 antibodies were used. 
Overexpression of SIRT1 decreased cellular proliferation and contact-independent growth in soft agar in prostate cancer cell lines indicating tumor suppressing action of SIRT 1 on LNCaP prostate cancer cell line ${ }^{11}$. Our results also suggest that SIRT2 might have an anti-tumorigenic qualities against prostate cancer similar to SIRT1, and further characterization is under way in your laboratory.

Although SIRTs are generally considered a tumor suppressor in normal tissues, their expressions have been reported to be upregulated in various cancers. SIRT1, for example, has been reported to be significantly overexpressed in human prostate cancer tissue samples compared with normal prostate tissue samples ${ }^{20}$. It is currently not clear whether SIRT2 has dual roles as a tumor suppressor in noncancerous tissues while having oncogenic roles cancerous tissues. SIRT2 overexpression in cancerous tissues might be due to a broken feedback loop, and furthermore other dominant pathways might induce the activity of AR in advanced stages of prostate cancer. Therefore, it will be important to determine that whether a SIRT2 activator or inhibitor should be used may depend on the stage or grade of the prostate cancer ${ }^{21}$.

In conclusion, understanding the regulation and complexities of the AR signaling and the modulation by SIRTs in the progression to prostate cancer is essential in developing preventative or treatment strategies using SIRT2 activators and inhibitors.

\section{Declaration of Conflicting Interests}

The author declares that he has no conflict of interest.

\section{Financial Disclosure}

No financial support was received.

\section{References}

1. SEER Cancer Statistics Factsheets: Prostate Cancer. National Cancer Institute. Bethesda, MD. Available at: http://seer.cancer. gov/statfacts/html/prost.html (Accessed: 24th March 2016).

2. Chen CD, Welsbie DS, Tran C, Baek SH, Chen R, Vessella R, Rosenfeld MG, Sawyers CL. Molecular determinants of resistance to antiandrogen therapy. Nature Med 2004;10:33-9.

3. Tan MHE, Li J, Xu HE, Melcher K, Yong EL. Androgen receptor: structure, role in prostate cancer and drug discovery. Acta Pharmacol Sinica 2015;36:3-23.

4. Lonergan PE, Tindall DJ. Androgen receptor signaling in prostate cancer development and progression. J Carcinog 2011;10:20.

5. Sadi MV, Walsh PC, Barrack ER. Immunohistochemical Study of Androgen Receptors in Metastatic Prostate-Cancer Comparison of Receptor Content and Response to HormonalTherapy. Cancer 1991;67:3057-64.
6. Deutsch E, Maggiorella L, Eschwege P, Bourhis J, Soria JC, Abdulkarim B. Environmental, genetic, and molecular features of prostate cancer. Lancet Oncol 2004;5:303-13.

7. Heinlein CA, Chang CS. Androgen receptor in prostate cancer. Endocrine Rev 2004;25:276-308.

8. Fu MF, Wang CG, Wang J, Zafonte BT, Lisanti MP, Pestell RG. Acetylation in hormone signaling and the cell cycle. Cytokine \& Growth Factor Rev 2002;13:259-76.

9. Fu MF, Rao M, Wang CG, Sakamaki T, Wang J, Di Vizio D, Zhang XP, Albanese C, Balk S, Chang CS, et al. Acetylation of androgen receptor enhances coactivator binding and promotes prostate cancer cell growth. Mol Cell Biol 2003;23:8563-75.

10. Gioeli D, Paschal BM. Post-translational modification of the androgen receptor. Mol Cell Endocrinol 2012;352:70-8.

11. Fu M, Liu M, Sauve AA, Jiao X, Zhang X, Wu X, Powell MJ, Yang $\mathrm{T}, \mathrm{Gu} \mathrm{W}$, Avantaggiati ML, et al. Hormonal control of androgen receptor function through SIRT1. Mol Cell Biol 2006; 26:8122-35.

12. Tao RD, Leclerc J, Yildiz K, Park SH, Jung B, Gius D, Ozden O. Changes in gene expression in SIRT3 knockout liver cells. Tr J Biol 2015;39:380-7.

13. Kim HS, Vassilopoulos A, Wang RH, Lahusen T, Xiao Z, Xu X, Li C, Veenstra TD, Li B, Yu H, et al. SIRT2 maintains genome integrity and suppresses tumorigenesis through regulating APC/C activity. Cancer Cell 2011;20:487-99.

14. Park SH, Zhu YM, Ozden O, Kim HS, Jiang HY, Deng CX, Gius D, Vassilopoulos A. SIRT2 is a tumor suppressor that connects aging, acetylome, cell cycle signaling, and carcinogenesis. Translational Cancer Res 2012;1:15-21.

15. Ozden O. SIRT2-JAK1 Interaction Decreases IL-6 Induced Inflammatory Response in Cancer Cells. Kafkas Univ Vet Fak Derg 2015;21:813-7.

16. Dai Y, Ngo D, Forman LW, Qin DC, Jacob J, Faller DV. Sirtuin 1 is required for antagonist-induced transcriptional repression of androgen-responsive genes by the androgen receptor. $\mathrm{Mol}$ Endocrinol 2007;21:1807-21.

17. Ozden O, Park SH, Wagner BA, Yong Song H, Zhu Y, Vassilopoulos A, Jung B, Buettner GR, Gius D. SIRT3 deacetylates and increases pyruvate dehydrogenase activity in cancer cells. Free Radic Biol Med 2014;76:163-72.

18. Fraga MF, Agrelo R, Esteller M: Cross-talk between aging and cancer - The epigenetic language. Biogerontol Mech Intervent 2007;1100:60-74.

19. Visakorpi T, Hyytinen E, Koivisto P, Tanner M, Keinanen R, Palmberg C, Palotie A, Tammela T, Isola J, Kallioniemi OP. In-Vivo Amplification of the Androgen Receptor Gene and Progression of Human Prostate-Cancer. Nature Genetics 1995;9:401-6.

20. Jung-Hynes B, Nihal M, Zhong WX, Ahmad N. Role of Sirtuin Histone Deacetylase Sirt1 In Prostate Cancer A Target For Prostate Cancer Management Via Its Inhibition? Journal of Biol Chem 2009;284:3823-32.

21. Karadağ MA, Çeçen K, Demir A, Bağcıŏglu M, Kocaaslan R, Sofikerim M. Prostat kanserinde fokal tedavi alternatifleri. Kafkas J Med Sci 2015; 5(1): 18-24. 